\title{
Management Repercussions Of The Increased Tax On Americans Working Overseas
}

\author{
Martin A. Goldberg, (E-mail: MGoldberg@ newhaven.edu), University of New Haven \\ Cynthia Kruth, University of New Haven \\ Mary J. Miller, University of New Haven
}

\begin{abstract}
The Tax Increase Prevention and Reconciliation Act of $2005^{1}$ extended expiring tax-reduction provisions, and created new ones. However, not all of TIPRA's provisions reduce taxes. Many Americans working abroad ended up paying higher income taxes, retroactive to the beginning of 2006. This created new managerial challenges for companies that have hired Americans in overseas positions, companies that have previously attempted to accommodate the additional costs these workers incur, and raises serious tax policy questions.
\end{abstract}

\section{INTRODUCTION}

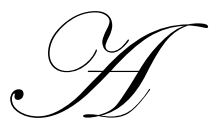

$\mathrm{n}$ individual who is a citizen or resident of the United States will pay U.S. income taxes on income earned while residing abroad. Historically there have been provisions of the Internal Revenue Code (the "Code") designed to mitigate some of the effect of the double tax, U.S. and foreign, on this income, as well as to offset in part the high cost of living in certain overseas locations. Once an individual has taken maximum advantage of these protective tax provisions, however, the financial burden of being an American working overseas can be high.

Extending the reach of the double tax regime were novel provisions in the American Jobs Creation Act of $2004^{2}$ ("AJCA") related to citizenship. "Prior to the enactment of the AJCA, the tax code definition of citizenship relied on the nationality law definition of citizenship: a person was treated as a citizen for tax purposes if, and only if, she was a citizen under the nationality law. The enactment of the AJCA broke this direct link between the tax code and nationality law, at least in certain circumstances, and it is now possible for an individual to be treated as a citizen for tax purposes during a period when she is not a U.S. citizen under nationality law.

"The ACJA provisions that added sections 877(g) and 7701(n) to the Internal Revenue Code focus on a particular group of individuals: those who had been U.S. citizens but who renounced or otherwise lost their citizenship under the nationality law." 3

Of broader reach was the Tax Increase Prevention and Reconciliation Act of $2005^{4}$ ("TIPRA"), signed into law by President Bush on May 17, 2006. This was a massive law that extended many expiring tax-reduction provisions, and created new ones. Among its tax-relief provisions were:

\footnotetext{
${ }^{1}$ P.L. No. 109-222, May 17, 2006

${ }^{2}$ Pub. L. No. 108-357, October 22, 2004

${ }^{3}$ Michael S. Kirsch, "The Tax Code as Nationality Law," Harvard Journal on Legislation, 43 Harv. J. on Legis. 375, 377, internal citations omitted.

${ }^{4}$ Pub. L. No. 109-222, May 17, 2006
} 
- Lower rates on capital gains and dividend income that were scheduled to expire at the end of 2008 were extended, so that they are now scheduled to expire at the end of 2010.

- $\quad$ The alternative minimum tax exemption for individuals, which was scheduled to drop in 2006, has instead been increased for that year, with the scheduled drop postponed to 2007.

- $\quad$ Starting in 2010, eligibility for conversions to a Roth IRA will not be limited to individuals with $\$ 100,000$ or less of a modified adjusted gross income, and for conversions in 2010 only, the tax liability can be paid for the 2011 and 2012 tax years.

- $\quad$ A higher first-year expensing deduction of $\$ 100,000$ (adjusted for inflation), which was scheduled to expire for tax years beginning after 2007 , is extended two more years before reverting back to $\$ 25,000$.

Unfortunately for certain taxpayers, TIPRA also included some tax-increase provisions, notably the increase in age at which the "kiddie tax" would apply, from 14 to 18 , and an increase in tax liability for certain individuals with foreign earned income. Of special note is that both of these increases were retroactive, effective at the beginning of the year 2006.

This article focuses on the increase in tax liability for certain individuals with foreign earned income, generally speaking, American citizens and residents working abroad. While originating as a taxpayer problem, this tax increase quickly became a management problem.

This is because employers often provide subsidies to Americans, to offset, in whole or in part, the additional taxes and living costs they have to incur. Management is now considering its options, one of which is simply to stop hiring Americans, as being just overpriced.

A note on terminology may be helpful here: The authors are aware of at least three different usages for the word "expatriate," or "expat." One meaning is an individual who has given up his or her citizenship, usually for tax advantages, more often referred to as an expatriate. This is the type of individual targeted by ACJA, which essentially created a waiting period before the tax law will recognize a relinquishment of citizenship.

The second meaning is used by foreign businesses, which is simply a category of employee who receives special subsidies to offset additional taxes and living costs. In this definition, a U. S. citizen working abroad who did not receive treatment different from any other employee would not be considered an expat.

The third definition, and the one generally used in this article, is simply a U. S. citizen or permanent resident working abroad, that is, the individual who is subject to U. S. taxes and eligible for partial relief from those taxes because of having earned wages abroad. A worker in either of the last two categories is more frequently referred to as an "expat" rather than "expatriate."

\section{THE TIPRA CHANGES}

The starting point for examining these changes is the fact that someone who is a citizen or resident of the United States will pay U.S. income taxes on income earned while residing abroad. Additionally, Americans sometimes find that their housing costs are much higher in global commercial centers like Singapore, Hong Kong, and Tokyo than they would be in the U.S.

Internal Revenue Code (“Code”) $§ 911$ provides two exclusions from gross income for individuals burdened by these higher costs: one exclusion for a portion of the individual's "foreign earned income" (the foreign earned income exclusion also known as "FEIE") and another exclusion for a portion of the individual's "housing cost amount." The first is simply an exclusion from gross income for amounts earned overseas, subject to a dollar maximum. The second can be either an exclusion from gross income (to the extent paid by the employer) or a deduction (to the extent paid by the employee) for housing costs in excess of a base amount.

\footnotetext{
${ }^{5}$ Code $\$ 911(a)$
} 
TIPRA, which became law on May 17, 2006, made several changes to the rules applicable to these exclusions, retroactive to the beginning of 2006. To illustrate the immediate effect that these changes had in 2006, this is the before-and-after comparison:

\section{Change \#1: Increase in the Amount of the Foreign Earned Income Exclusion}

Prior law: The amount of the foreign earned income exclusion was $\$ 80,000$, to be adjusted for inflation starting in 2008 , using 2006 as a base year.

New law: The amount of the foreign earned income exclusion is $\$ 80,000$, adjusted for inflation starting in 2006, using 2004 as a base year. $\$ 82,400 .^{6}$

2006 numbers: This change increases the foreign earned income exclusion for 2006 from $\$ 80,000$ to

\section{Change \#2: Increase in the Base Housing Amount}

Prior law: Housing costs could be excluded or deducted from gross income to the extent that they exceed a base amount, calculated as 16 percent of a U.S. government worker at step 1 of grade GS-14.

New law: Housing costs can be excluded or deducted from gross income to the extent that they exceed a base amount, calculated as 16 percent of the foreign earned income exclusion.

2006 numbers: This change increases the base housing amount for 2006 from $\$ 12,447$ to $\$ 13,184$.

These first two changes are fairly minor. However, there are other changes that could cause a major increase in the U.S. tax liability for an American working abroad.

\section{Change \#3: Creation of a Maximum Housing Amount}

Prior law: Once a taxpayer was over the base amount, there was no limit on the exclusion or deduction, other than the general reasonableness requirement applicable to many deductions.

New law: The maximum housing amount that can be excluded or deducted is equal to $30 \%$ of the maximum foreign earned income exclusion, minus the base housing amount. Since the base housing amount is 16 percent of the foreign earned income exclusion, netting these two calculations means that the maximum amount that can be excluded or deducted will generally be 14 percent of the foreign earned income exclusion. The law authorizes the IRS to adjust this upwards or downwards for specific geographical areas, and one announcement on this has already been issued. ${ }^{7}$

2006 numbers: This change goes from no dollar maximum at all, to an $\$ 11,536$ maximum exclusion or deduction for housing costs in excess of the base amount. This is determined as follows: $30 \%$ of $\$ 82,400$ is $\$ 24,720$. Subtracting from that the $\$ 13,184$ base housing amount leaves a maximum of $\$ 11,536$ of housing costs that can be excluded or deducted. As noted, the IRS has increased the $\$ 24,720$ ceiling for certain specific areas. ${ }^{8}$

\section{Change \#4: Tax Bracket Increased by Adding Back Exclusions}

Prior law: After the Code $\S 911$ exclusions, the taxpayer simply calculated his or her tax liability using the same brackets as everyone else.

\footnotetext{
${ }^{6}$ Rev. Proc. 2006-51, 2006-47 I.R.B. 945 (Nov. 3, 2006)

${ }^{7}$ Notice 2006-87; 2006-43 IRB 1, discussed more fully in Part III, below.

${ }^{8}$ Id.
} 
New law: Both the foreign earned income exclusion and the housing cost amount are added back to the taxpayer's income for purposes of determining the marginal brackets that the taxpayer will have to use in determining his or her tax liability.

2006 numbers: The exact numbers will vary from person to person. By way of example, if the exclusions push someone from a 25 percent marginal bracket to a 35 percent marginal bracket, that is a 40 percent increase in tax liability. Perversely, this provision only increases the tax liability of workers who are not otherwise at the top bracket, so it is a tax increase from which the wealthy are exempt. In other words, it is a punitive addition to income taxes for mid-level managers and executives.

It is not impossible, but it is difficult, to come up with an example of an individual who will have a net benefit from these changes. Such a person would have to have little or no income other than the overseas wages, and work in a country with low housing costs. Many more people will be hurt, and the ones hurt the most will be individuals who work in areas with high housing costs.

A separate tax law provision, Code $\S 901$, provides a tax credit against U.S. taxes for taxes paid to foreign countries. While this somewhat ameliorates the overall tax burden of American workers overseas, it only benefits those in countries with higher taxes than the U.S. If the worker is located in a place with high housing costs and low local taxes (such as Hong Kong or Singapore), then the worker is denied any net benefit of the credit, but still has the increased tax burden of the recent changes to Code $\$ 911$. Because European nations tend to impose income taxes at a higher rate than the United States, meaning that U.S. workers in those countries often pay no U.S. tax at all, the Code $\$ 911$ changes tend to have less or no effect on workers in those countries.

\section{IRS NOTICE 2006-87}

On October 23, 2006, the Internal Revenue Service published Notice 2006-87. ${ }^{9}$ This Notice was issued pursuant to the authority granted by TIPRA to establish housing exemptions different from the base amount stated in the statute, for specific geographic locations.

Although any relief was regarded by expats and their employers as an improvement, the relief granted by the IRS was partial and inconsistent. For instance, under this new IRS notice, the dollar maximum for housing exclusion in Hong Kong is $\$ 101,116$, while the dollar maximum in Singapore is $\$ 29,716$. (These numbers appear in the Notice as $\$ 114,300$ and $\$ 42,900$, respectively, however the numbers in the Notice do not reflect the reduction for the base housing amount -- $\$ 13,184$ for 2006.) While it is generally acknowledged that housing is more expensive in Hong Kong, expats in Singapore question whether it is three times more expensive.

Notice 2006-87 was expanded by Notice 2007-25. ${ }^{10}$ This second notice modified the limitations for several of the locations. It also added new locations that had not been included in the original notice.

These two Notices were controversial from the start. First, there was the question of disparities between different locations, such as the disparity between Hong Kong and Singapore.

Second, there was the question of individuals living in suburbs, that is, individuals whose residences were not strictly within the city limits of a designated city, but still in the same general cost-of-living range. For instance, Tokyo has one of the highest housing allowances, and yet only the default housing rate is available to someone commuting from just outside of the city.

Third, there is little explanation as to why some localities are omitted completely. In some cases entire countries are covered, while in other cases only a handful of cities are covered.

${ }^{9}$ 2006-43 IRB 1, Oct. 23, 2006

${ }^{10}$ 2007-12 I.R.B. 760 (Mar. 19, 2007) 
Fourth, the arbitrariness of both timing and amount frustrate any sense of fair notice for planning. Taking a look at a particularly egregious example, Osaka-Kobe, Japan.

When TIPRA was passed, Osaka-Kobe was eligible for the default maximum housing allowance amount of $\$ 11,536$ for 2006 . Notice 2006-87 increased that modestly to $\$ 15,316$. Then Notice 2007-25 increased that to $\$ 39,852$. As nice as that last increase must have been for U. S. citizens who were Osaka-Kobe residents, the notice was published approximately one month before the due date for 2006 income tax returns, and certainly well after the end of the taxable year. It is not at all inconceivable that an individual would make reasonable financial and career plans based on the more modest number, which in retrospect turned out to be wrong. This fundamental arbitrariness makes ordinary planning difficult, if not impossible. Taking into account that this individual has already had to recalculate his taxes for 2006 after the retroactive application of TIPRA, this means that between April 2006 and April 2007, this person's 2006 tax liability would have been calculated four different ways: first, pre-TIPRA, second, post-TIPRA but pre-Notice 2006-87, third, after the first notice but before the second, fourth, post-Notice 2007-25.

\section{MANAGEMENT ISSUES}

As we have seen in the last section, the Code $\S 911$ changes can wreak havoc with individual planning. Perhaps a problem with wider significance is the havoc that is caused in management planning.

Originally, when the foreign earned income exclusion and the housing cost exclusion were fairly stable, overseas employers tended to have different approaches towards handling U. S. employees:

- $\quad$ One approach would always be do treat U. S. citizens the same as other employees. This approach would rarely attract U. S. citizens because they would feel they could not afford additional taxation and housing costs.

- $\quad$ Another approach would be for the overseas employer to pay the U. S. employee a fixed amount of additional compensation, designed to offset part or all of the additional costs.

- $\quad$ Finally, an employer could have additional compensation determined by formula, so that whatever additional costs an employee would have would be compensated.

Although the last of these alternatives is the most favorable to the employee, it would result in a disaster to the employer. TIPRA raised taxes retroactively, not uncommonly tens of thousands of dollars, so an employer using a formula would find a large and very unexpected increase in costs.

Given the harsh surprise of 2006, it's not likely that many employers going forward will sign a blank check in terms of reimbursing the employee for whatever the additional taxes and housing costs might be. More likely, if there is any additional compensation at all, it will be a fixed amount.

However, going forward there is an additional alternative, and that is that overseas companies will simply stop hiring U.S. workers. It may simply be that given the additional cost that the workers will have to pay, that one way or another hiring a U. S. worker will not be considered a good investment.

Although the Code $\$ 911$ changes do not explicitly target mid-level workers, in fact they will bear the brunt of these changes, for two reasons: First, in the case of top executives, it is more likely that their companies will be willing to pay whatever is necessary to retain them. Second, the new bracket shift will only affect individuals who are not already at the top tax bracket. The bracket shift will not have any affect on a person whose income from all sources already places him or her at the top bracket.

"For example, consider an unmarried employee living in country X earning a salary of $\$ 500,000$ and receiving, in addition, an employer-provided housing allowance of $\$ 50,000$. [In 2005], the employee could have excluded $\$ 80,000$ of his salary from his U.S. taxable income as an FEIE. In addition, the employee could have excluded $\$ 37,810$ of his housing allowance from his taxable income. As a result, his U.S. taxable income would be 
$\$ 432,190 \ldots$ [In 2006, t] he new rules allow $\$ 82,400$ to be excluded from U.S. taxable income, but the housing cost amount is now limited to $\$ 12,273$. As a result, the employee would have taxable income of $\$ 455,327$. Under the new rules, the employee's U.S. taxable income is increased by $\$ 23,137$, and U.S. income tax is increased by $\$ 19,785$, ,"11

Another factor is the impact that the new law has on the U.S. credit for foreign taxes paid. "U.S. employees who pay income taxes in the foreign jurisdictions in which they work will usually be entitled to claim a credit in respect of foreign taxes paid. However, no credit is allowable for foreign taxes paid on income that is excludable under Section 911."12 Thus, the new law increases the individual's taxes in part through the bracket shift, but this increase in taxes cannot be offset by the credit because it does not increase the foreign taxes paid.

The cost of additional taxes and housing costs have not historically been borne entirely by the employee. Employers often try to subsidize additional employment-related costs paid by their American employees. The result of this will be that U.S. managers and executives will be less desirable employees to foreign business operations. Foreign companies will be forced to reconsider whether they want to hire U.S. citizens, and even U.S. companies with operations abroad will have new incentives to replace their American employees with non-Americans.

The executive director of the American Chamber of Commerce in Singapore, Nicholas de Boursac, has been a vocal opponent of the legislative changes.

"US companies here have sought out tax consultants to figure out what the impact will be, says Mr. de Boursac. ... [I]t looks like the tax bill will go up by a hefty US $\$ 25,000$ or more for some individuals, he notes.

"'That's pretty significant. At the end of the day, the consumer pays, right, there's no free lunch. So somebody has to pay. Either the employer pays for it, and asks himself, why am I hiring an American rather than an Australian who can do this job? Or the individual pays for it, and asks, why do I need to pay more to be able to stay here?'

"He adds: 'I'm convinced that some people are going to go back to America as a result of this who would normally be out there selling American goods."”13

Regardless of whether a U. S. tax on its citizens working overseas can be justified with internal logic, in a broader context it skews the playing field on which U. S. workers will need to compete. "Traditionally, the United States has been among the most aggressive countries in exercising taxing jurisdiction abroad. The United States is the only major country that taxes the worldwide income of its citizens even if they live outside the country." 14

As one editorial noted: "The United States is the only developed country that imposes worldwide income tax on its citizens working overseas. Tax experts say that new taxes on Americans working abroad could prompt U.S. companies to start hiring employees from places like Britain and Canada, while provoking American executives in Europe and Asia to return home." ${ }^{15}$

In the words of Lucy Stensland Laederich, an American translator based in Paris: "We are 4.1 million ambassadors living outside the U.S. ... We buy American products, fly American airlines, send our children to American universities and improve the image of Americans overseas. Why are we being punished?"16

\footnotetext{
11 Arthur H Kohn, Katie Sykes, Jeffrey R Penn, "Recent Changes to U.S. Federal Income Tax Rules for U.S. Employees Relocated Abroad," Employee Benefit Plan Review, Aspen Publishers, Inc., Aug. 2006.Vol.61, Iss. 2; pg. 10.

${ }^{12}$ Id.

13 Anna Teo, "Battling the 911 of US tax rule," The Business Times Singapore, Singapore Press Holdings Limited, August 12, 2006.

${ }^{14}$ Michael S. Kirsch, “The Tax Code as Nationality Law,” Harvard Journal on Legislation, 43 Harv. J. on Legis. $375,377$.

${ }^{15}$ Dan Bilefsky, “Americans abroad outraged over tax changes," International Herald Tribune, May 16, 2006.

${ }^{16}$ Id.
} 
The negative response to this is not limited to overseas workers and industry groups. In fact, a former chair of the House Ways and Means Committee, Bill Archer (R-Texas), now a senior policy analyst at Pricewaterhouse Coopers, has spoken against the changes.

Archer noted in an interview that "...fewer Americans will be employed [overseas] because it will be cheaper to employ foreigners and that has a negative impact on the economy of the United States because when Americans are employed overseas they will order parts and services from the United States. If a foreigner is employed by a US corporation, they are inclined to order parts and services from their own home country. This is, again, a totally backwards approach to what we need to be competitive in the world marketplace... Many corporations subsidize their employees and increase their pay to offset the increased taxation. But, many employers do not. And so sometimes it hits very hard at the employee that is not anticipating having a reduced net income and sometimes it simply shows up in the corporation's expenditure column. In both cases, it is contrary to the best interest of the United States because we should want more Americans working overseas in order to prevent those jobs from being outsourced to foreigners." 17

What is the likelihood of repeal of these changes? Unfortunately, Code $\$ 911$ is inherently controversial. One point of view is that it is an unwarranted subsidy to overseas workers and should be repealed entirely. On the opposite extreme is the view that few other nations, and no other developed nations, impose a domestic tax at all on their overseas workers, and if the U.S. is going to be out of step with international norms then it is appropriate to have generous offsets to compensate for this unusual burden.

\section{POLICY ISSUES}

The foreign earned income exclusion was first enacted in 1926, based on compelling testimony, in so many words, that "Americans buy American." The theory was that Americans overseas would purchase U. S. goods while abroad. Although there were changes to the foreign earned income exclusion over the years, this underlying premise had not actually been tested, until 1978 when the exclusion was repealed. Instead of the exclusion, there were targeted deductions designed partially to offset the additional costs of working abroad.

The 1978 tax law change met with a great deal of resistance. "Congress reinstated the exclusions retroactively in 1981 after the impact of their elimination on U. S. exports was documented."18

A scathing critique was issued by the General Accounting Office, in a report titled, "American Employment Abroad Discouraged by U. S. Income Tax Laws." 19 According to the report:

The competitiveness of U. S. exports in the world market has become a major national concern because of the deficit in the U. S. balance of trade that developed in the 1970s and its implications for real income and employment in the United States. This problem has been the focus of major initiatives to improve Government export promotion programs and to identify and correct Government disincentives to exports.

To adequately promote and service U. S. products and operations in foreign countries, $U$. S. companies employ a large force of U.S. citizens abroad. There is widespread concern that tax provisions contained in the Foreign Earned Income Act (FEIA) (Public Law 95-615, Title II, Nov. 8, 1978) are proving a disincentive to employment of U. S. citizens abroad, and, therefore, adversely affecting exports.

\footnotetext{
${ }^{17}$ Podcast interview with The Tax Foundation, a non-profit, non-partisan tax research organization based in Washington, DC, on August 1, 2006, on its web site at http://www.taxfoundation.org.

${ }^{18}$ Paula N. Singer, “U. S. Policy on Taxing Citizens and Residents Abroad: A Closer Look,” Tax Notes International, page 1003, 42 Tax Notes Int'1 1033 (June 19, 2006)

${ }^{19}$ ID-81-29, February 27, 1981
} 
A GAO survey of a group of major U. S. companies having substantial operations abroad revealed that U. S. taxes were an important factor in reducing the number of Americans employed overseas, because the:

- Tax laws do not fully relieve the companies' employees from taxes on income reflecting the excessive costs of living and working abroad.

- $\quad$ Companies generally reimburse overseas employees for their additional tax burden, making Americans more costly than citizens of competing countries, who generally are not taxed by their home countries.

- $\quad$ Complexity of the new tax laws makes compliance difficult and expensive. ${ }^{20}$

In 1981, the repeal of the foreign earned income exclusion was reversed retroactively, and the current version of the foreign earned income exclusion was enacted. Although dollar limits have been changed over the years, it was in 1981 that the present two-part exclusion was enacted, the basic foreign earned income exclusion, plus the excess housing cost exclusion, both of which are sometimes referred to collectively as the "section 911 exclusions."

Although the primary argument in favor of these exclusions was the fact that Americans buy American, and that increased employment abroad was good for U. S. exports, a second argument has emerged over the years. That is, U. S. citizens overseas are goodwill ambassadors for the U. S., an argument that has been restated with increased fervor in light of worldwide conflicts. There is also the reverse side of the "goodwill ambassadors" argument, and that is that overseas workers returning home bring with them greater understanding of the countries they visited.

Although these arguments have been disputed, ${ }^{21}$ we have already seen in the 1978-1981 period the deleterious affect of repealing the foreign earned income exclusion.

\section{CONCLUSION}

Tax treatment of U.S. citizens and permanent residents working overseas has gone through many changes over the years. There are basically two reasons for this. First, the U. S. is one of the only countries that taxes its citizens on income received for services rendered in other countries. Second, American lawmakers are ambivalent about what are the policy goals served by providing tax relief to overseas workers.

Unfortunately, the changes themselves make for bad policy, and now make it difficult for overseas employers to hire U. S. workers at all. Congress needs to establish, once and for all, a policy that recognizes the value of having workers overseas. Inherent in that would be a repeal of the 2006 changes, and progressive increases in the foreign earned income exclusion and housing cost exclusion.

\footnotetext{
${ }^{20}$ Id., p. i.

${ }^{21}$ Michael S. Kirsch, "Taxing Citizens in a Global Economy,” New York University Law Review, 82 N.Y.U.L. Rev. 443 (May, 2007)
} 